\title{
Enforced disappearance as a form of psychological torture: evidence from the Ayotzinapa case (México)
}

\author{
Natalia Huerta Pérez¹, Edith Esgareño,2
}

\section{Key points of interest}

- The enforced disappearance of the 43 Ayotzinapa students in Mexico shows how impunity and repeated lies and mistreatment of family members by the State are configured as an element of psychological torture and should be qualified as such.

\section{Abstract}

Objective: To analyse the impacts of enforced disappearance as a form of psychological torture in the enforced disappearance of 43 students known as the Ayotzinapa Case (Mexico). To make visible the effects of impunity.

Method: Historical and documentary analysis. Interviews with two groups of people affected: 1) relatives of the 43 young students who disappeared; 2) young students that survived. Analysis of the information obtained from the group and individual clinical interventions carried out during three months.

Results: In both groups, various impacts related to political violence were identified, in

1) Psychologist and humanitarian worker in contexts of violence. Correspondence to: 1.nataliahuerta@gmail.com

2) Psychologist. Independent researcher. particular enforced disappearance, which leads us to consider that the criteria for torture are fulfilled and especially the elements derived from the subsequent re-victimising action of the State in the investigations and the impunity derived from the lack of access to justice and truth.

Conclusion: In addition to the enforced disappearance itself and its impacts, the suffering resulting from the State's subsequent processes must be analysed.

Keywords: Psychological torture, enforced disappearance, impunity.

\section{Introduction}

The context of serious human rights violations in Mexico has been reflected in numerous reports from national and international organisations that refer to instances of arbitrary detentions, torture, extra-judicial executions, enforced disappearances by authorities and organised crime actors under cover of the State. These violations have caused damage to numerous victims throughout the country.

Enforced disappearance is not a recent issue in Mexico. According to the latest figures offered by the Undersecretary of Human Rights Alejandro Encinas, there are $\mathbf{8 1 6 1 7}$ missing persons and 8417 unaccounted for since 1964 (90.344 in total). The vast majority happened after 2006, as a consequence of the so-called "declaration of war" 
that the then-President Felipe Calderon ${ }^{1}$ made against drug trafficking in the name of national security. On the other hand, 3,978 clandestine graves have been registered throughout the country, where 6,625 bodies have been exhumed; of this total. More than 50.000 bodies remain unidentified in the country. (Secretaría de Gobernación, 2020).

In 2013, Human Rights Watch shared a report documenting the cases of 249 persons who disappeared in Mexico since December 2006. In 149 of these cases, they found evidence that state that actors participated in the disappearance, either on their own or in collaboration with criminal organisations, involving members of all security forces taking part in public security operations: the Army, Navy, Federal Police, and state and municipal police.

This paper aims to reflect on the impacts of the relatives of the case Ayotzinapa and the role of the State in their suffering as elements that fulfill the United Nations definition of torture, in this case, psychological torture (Pérez-Sales, 2017).

\section{Enforced Disappearance: The Ayotzinapa Case}

On the night of September 26th, 2014, a group of students from the Raúl Isidro Burgos Rural Normal School in Ayotzinapa (Guerrero), in southern Mexico, were attacked by municipal police while travelling in five buses in the city of Iguala, in the same State. The Ayotzinapa normalistas were attacked five times during four consecutive hours. As a result of several attacks, six students were killed (three students of the Normal, one of them tortured and skinned), firearms wounded twenty-four,

1 Former president of Mexico's National Action Party (PAN) who served from 2006 to 2012. four with severe consequences, and fourtythree disappeared (Hernández, 2016).

There were three scenarios.

On the first one, three buses were stopped by the local police at the city's exit, where the first attack with firearms took place. Fifteen students got off the first two buses and protected themselves between the first and second buses while police officers shot at them. The youngsters from the third bus were pulled out, with their hands up, subdued by the police and were left lying on the ground in a line while guns were pointed at them. They were then taken away in Iguala police patrol cars (GIEI, 2015). During this time, several normalistas made calls asking for an ambulance to attend to the wounded. One of the calls was disregarded as false, and in another, the students were informed that the police had prevented the ambulance from accessing the site. About half an hour after the calls, a university ambulance evacuated the injured (GIEI, 2015).

Another scenario took place at the exit of Iguala on the way to Chilpancingo (Guerrero), where the fourth bus was going. All the normalistas (43) on it were detained and disappeared, so there are no direct testimonies of what happened (GIEI, 2015).

The fifth bus that followed was stopped and interrogated by the local police, and, amidst threats and shouts, they ordered them to get off and leave the place as best they could. The students also reported a presence of Federal and State police (Mónaco, 2015).

Some students regrouped and tried to protect the evidence where the events occurred and started to talk to journalists on the spot. While the press conference took place, they were attacked again by at least three people dressed in black and hooded (GIEI, 2015). Two students were killed (Daniel G. and Julio R.), and another (Edgar V.) was seriously wounded with a bullet in the mouth. The ter- 
rified students ran in different directions to save their lives. Julio César $M$. was separated from the group while trying to escape. The normalistas did not hear from him again until the next day, his body was found with visible signs of torture and his face flayed (Antillón, 2016).

Some students went to the prison in the early morning hours to get information about their colleagues detained by the police. The police informed them that the students had not been there.

\section{Impunity: a State response}

Although it is not the purpose of this study to delve into the severe contradictions found by the Argentine Forensic Anthropology Team (EAAF) and the Interdisciplinary Group of Independent Experts (GIEI) concerning the official version issued by the Attorney General, it is essential to analyse situations that aggravated the psychosocial impacts on the relatives, increasing the mistrust and suffering of the parents.

The Attorney General of the Republic (PGR), on November 7th, 2014 (33 days after the events) publicised the conclusions of the official investigation claiming "that the normalistas were handed over by municipal police to the criminal group "Guerreros Unidos" 2 who incinerated them in the Cocula garbage dump and then threw their ashes in bags into the San Juan River (González, 2017). He mentioned an alleged link between the students and the criminal group that would have executed them.

The collaboration of the EAAF was decisive in the case. EAAF, an organisation of forensic anthropology, international prestige, and

2 The Guerreros Unidos cartel is a criminal organisation that operates mainly in the states of Morelos and Guerrero, and was consolidated in 2011. considered a reliable source of high technical qualification and neutral by the relatives, published a communiqué ${ }^{3}$ in which it questioned the PGR's version based on the evidence they collected on the spot (González, 2017).

The lack of empathy on the attorney general at the time ${ }^{4}$, and the late response of the president of $\mathrm{Mexico}^{5}$, conveyed the message that the State did not consider this case relevant. The latter, reacting to the demands of the relatives, publicly expressed their weariness with the issue and recommended turning the page and "getting over the pain". Such response had a hopeless and painful effect on the relatives, who feared that the search would stop.

On January 25th, 2015, the PGR held another press conference, in which high-level officials indicated that the statement of a new detainee and the skeletal remains found in the Cocula landfill and the San Juan River confirmed the version of events disseminated in November 2014 and giving the case as closed (Antillón. 2016).

For seven years, the students and the relatives of the students who disappeared continued to demand an investigation into what happened that night and request information on the whereabouts of the 43 young people who have never been heard from again.

\section{Ayotzinapa as an example of enforced disappearance in Mexico}

The Ayotzinapa case is emblematic, as it reveals the characteristics of enforced disappearance in Mexico. It shows the participation

3 It is available on the EAAF website: http://www. eaaf.org/files/comuni-cado-eaaf_7feb2015.pdf.

4 Consult at: https://www.animalpolitico. com/2014/11/ya-canse-murillo-karam-explicaesa-frase-tres-dias-despues/

5 Available at: https://expansion.mx/ nacional/2014/12/04/pena-nieto-guerrero-visitaplan-seguridad-ayotzinapa-43-normalistas 
of various forces of law and order in collusion with organised crime in execution, torture and enforced disappearance against a student population, characterised by precariousness and linked to social movements in the region. Official investigations are a necessary auxiliary to guarantee impunity. (Illades, 2015).

Around Ayotzinapa, several exhaustive journalistic investigations have been carried out. The authors analysed the events in detail, explaining the participation of the different security forces and questioning the official version (Hernández, 2016). Texts and documentaries have also been produced to recover the voice of the victims through dialogue with the families and with some surviving and non-disappeared normalistas, bringing them closer to the reader with names and faces (Mónaco, 2015).

The role mentioned above of the EAAF has also been fundamental. A rigorous technical analysis concluded that there was no consistency between the forensic evidence and the testimonial evidence obtained under torture from the alleged perpetrators by the Attorney General's Office (PGR). Also decisive was the report of the Interdisciplinary Group of Independent Experts (GIEI), which came based on a technical assistance agreement signed in November 2014 between the Inter-American Commission on Human Rights (IACHR), the Mexican State and representatives of victims, as a result of pressure from the victims. Between March 2015 and April 2016, the GIEI compiled the progress of its investigation in two reports, formulating recommendations. The first report broadens and deepens the lines of investigation and documents part of the impacts on family members and survivors (GIEI, 2015). In the second, it focused on the elaboration of plans to search for the missing persons in the immediate hours after disappearance, while they were still alive, and on a technical analysis of the lines of inves- tigation to determine criminal responsibility. Furthermore, they made a technical analysis of the official Plan de Acción Integral a las Víctimas (Plan of Comprehensive Attention to Victims), recommending a new and independent study of the psychosocial and health impact on the victims of the Ayotzinapa case ${ }^{6}$ (Antillón, 2016). The State followed the recommendations by forming a multidisciplinary group that designed a new proposal of psychological care and reparation of damages, issued too many years after the events and due to public pressure.

Enforced disappearance of persons is a multiple and continuing human rights violation closely related to the prohibition of torture and other inhuman or degrading treatment. ${ }^{8}$ The Declaration on the Protection of All Persons from Enforced Disappearance reiterates that "any act of enforced disappearance places the victim outside the protection of the law and causes severe suffering to the victim and his or her family ${ }^{9}$. It constitutes a violation of the rules of international law, which guarantee to every human being, inter alia, [...] the right not to be subjected to torture or other cruel, inhuman or degrading treatment or punishment. [...]”. (Alternative Report to the Committee against

6 Available at: https://www.oas.org/es/cidh/ actividades/giei/GIEI-InformeAyotzinapa2.pdf

7 I just wanted it to dawn: psychosocial impacts of the Ayotzinapa case.

8 Human Rights Committee, General Comment No. 31 of 29 March 2004 Nature of the general legal obligation imposed on States parties to the Covenant, para. 18. In the same vein, Working Group on Enforced or Involuntary Disappearances (WGEID), Annual Report for 1982, doc. E/CN.4/1983/14 of 21 January 1983, para. 131.

9 Art. 1, para. 2 of the Declaration on the Protection of All Persons from Enforced or Involuntary Disappearances (1992). 
Torture, 2012 $)^{10}$. For the family members, "they suffer slow mental anguish, not knowing whether the victim is still alive and, if so, where he is being held, in what conditions and what his state of health is. Moreover, aware that they too are under threat, they know that they may face the same fate and that the mere fact of inquiring into the truth may expose them to even greater danger..." (UN Office of the High Commissioner for Human Rights). In addition to the very traumatic impact associated with the experience, enforced disappearance and torture are distinguished from other traumatic events by the particular psychic and social disruptive effect of the involvement of State agents in them (Gravante, 2018).

On September 26th, 2014, with the enforced disappearance of the 43 students from Ayotzinapa, the execution of three others, and the physical and permanent injuries to two of them, the human rights crisis in the country, the impunity in the investigations, the abandonment of the victims by the State became visible. The case progressed in the hands of the relatives and their representatives, given the lack of real collaboration from the State, beyond empty promises and words.

\section{Methodology}

We analysed the information obtained from the therapy groups and from individual clinical interventions carried out during three months in the Ayotzinapa Normal School with the group of relatives of the disappeared and the surviving students to analyse the experience from the perspective of the victims themselves in their relationship with the State institutions involved.

10 Revised at: https://tbinternet.ohchr.org/Treaties/ CAT/Shared\%20Documents/MEX/INT_CAT_ NGO_MEX_12976_S.pdf
The information was collected through therapeutical group interventions designed by an iNGO in a pre-fixed format used in emergencies. The objective was to accompany and mitigate the suffering of the families of the disappeared and the surviving students.

For reasons of confidentiality, no tape recorder or camera was used. Following the preferences of the interviewees, most of the interviews were conducted in informal spaces such as gardens, the schoolyard or a classroom.

Impunity was understood as a set of political and media strategies whose purpose is to deny the facts or implant versions that hide the responsibility of the perpetrators and demobilise social demands for truth and justice (Antillón, 2016). Within the study of the impacts of torture, particular relevance was given to (a) the elements of fear and terror, the loss of control and the feeling of helplessness and their relationship with the chronic psychological damage described in torture victims (Pérez-Sales, 2017); (b) the harm documented in relatives through the reports of the GIEI and independent experts' report. Both emphasise how impunity and the lack of truth and justice operate as traumatic stimuli for victims; (c) specific literature describing how enforced disappearance can provoke specific symptoms or chronicle previous problems and in particular the existence of depression, sleep disorders, somatic disorders, suspension or abandonment of vital projects, feelings of impotence, hopelessness, rage, among others (Diana Kordon, 1991).

\subsection{Formation of intervention groups}

Three group interventions were carried out with 1) fathers of missing students, 2) mothers and 3) student survivors (Table 1).

\subsection{Couple and individual interventions}

Four couple-therapy sessions were offered to relatives of the disappeared, with three sub- 
Table 1. Intervention groups in Ayotzinapa

\begin{tabular}{|c|c|c|c|}
\hline Group & Participants & Sessions & Topics \\
\hline $\begin{array}{l}\text { Parents of the } \\
\text { missing students }\end{array}$ & 38 & 10 & $\begin{array}{l}\text { - Identification of basic needs } \\
\text { - Reconstruction of the facts: What happened } \\
\text { to the students? } \\
\text { - Sense of hopelessness in the face of the } \\
\text { State's response } \\
\text { - Emotional support when they received bad } \\
\text { news }\end{array}$ \\
\hline
\end{tabular}

Mothers of the dis- 18 appeared students

Student survivors
7

5
- Symptoms of stress

- Stress reduction techniques

- Narrative of the events of September 26th

- Emotions and fear concerning the disappearance of their classmates

- Changes in family dynamics

- Fear of being stigmatised by your community

- The guilt of being alive sequent follow-up sessions. Also, eight individual sessions were conducted with the three surviving students. In the first interviews, the objective focused on identifying the most basic needs, predominant symptoms, concerns, and support network. The following sessions focused on working with narratives and emotions.

\section{Results}

\section{Group 1: Student survivors}

The interventions with the group of students allowed us to identify seven categories of impacts related to the attacks of the night of September 26th and of which they were victims 1) terror derived from the events themselves, 2) subsequent fear derived from witnessing the execution of others, 3) posttraumatic stress symptoms (PTSD), 4) experiences of humiliation, 5) guilt for surviving, 6) fear of social stigmatisation, and 7) psychological damage. Taken together, they show the various forms of suffering that make up the psychological torture experienced by students. Some examples:

The shooting seemed to go on forever. I felt very scared when the bullets shattered the windows of the bus. I threw myself to the ground, covered my face for a few minutes and then I saw my companion bleeding. I thought they would kill us all, and then I would be next. I was paralysed for a long time, I wanted to go down to see the others, but fear got the better of me. (Fear and terror)

I was on the first bus, and I was saved. I stayed hidden, waiting for the others to come, but they didn't. The police took my companions. The police took my friends away. Why them? What if it had been me? It doesn't seem fair. I slept with two of the people they took away, and I can't sleep anymore. I see them at night; I wait for them. (Guilt, PTSD Symptoms) 
The image of Cesar with his face disfigured was uploaded to the networks, and that's how his wife found out. He was my friend, and I could not get it out of my head why him. Why did I save myself? He had just become a dad. More than sadness, I find it humiliating that he died like that [tortured and flayed]. (Guilt, Humiliation, PTSD Symptoms)

One of the narratives tells of the psychological consequences of police control and abuse of power, emphasising the role of the State.

One of the things that hurts me the most is remembering the indifference of the police when my partner was in serious condition. $\mathrm{He}$ was shot in the head, and they would not let the ambulance in. I feel anger, pain, sadness and sometimes hatred. Now it's like he's dead; he's in a coma. His life has been destroyed, his life and everyone's, we are no longer the same as before. (Humiliation, Psychological Damage)

These emotions and impacts had repercussions on the students' later lives. Three of them mentioned that, after what happened, they had not been able to return to the Normal school, partly because of the fear of being interrogated, partly because of the response of the people at the school itself.

The following accounts show the impact on life change after the events, as well as the fear of stigmatisation and the guilt of still being alive:

We were afraid to come. We don't know how things would be here. Our families are terrified, afraid that something will happen to us again. Some people think bad things about us, and maybe we are not perfect, but we didn't deserve to live through what happened. (Fear, Social stigmatisation)

At times I feel guilty for still being here. Especially when the parents of the disappeared ask me questions. I feel powerless, I can't even look them in the face. (Guilt, Social Stigmatization)

The price of having survived is to carry the memories in your body and not to forget them. Something of me died that day. (Grief, Guilt)

I can't fail my school, the place that has given me the opportunity to be someone. I already failed my friends who left; now I want to finish what I started. I don't deny that sometimes I do feel paralysed by fear. (Fear, Guilt)

Group 2: Parents of the missing students

Within the interventions with parents, six main conclusions were identified: 1 ) humiliation, 2) impunity, 3) family/social breakdown, 4) distrust of authorities, 5) physical/psychological harm and 6) guilt.

The parents mentioned a radical change in the lives of all family members. On the one hand, they are in search, and, on the other hand, they cannot take care of the rest of their children as before:

"ife is harder for us now. We are not the same. We have two other children, but my wife is sad, she cries a lot and has much pain in her back, and I am in the group of dads in demonstrations. Our youngest son has isolated himself and eats little, and I think we neglect him. However, the truth is, we don't know how to be "normal" parents again. We are very hurt, and we want to keep looking for 
our son [Family Breakdown, Physical and Psychological Harm].

The active role of women mothers, both to guarantee the economic income and care of their children and to participate in the search for their child, represents extra burdens that add to the emotional and physical impacts that each member of the family experiences (Martínez, 2006).

It is tough to go on with everything. My other children know I'm sick, but I don't know what to do. We live in Normal, and my other children are with me, but I want to leave them with my mom, but my husband says no. I can't take care of them now. I can't take care of them now.

The authorities' treatment of and response to the relatives increased confusion and uncertainty. The "historical truth" as the supposed endpoint of the investigation increased distrust and deepened the psychological damage generated by impunity. Added to this are the feelings of humiliation and pain in the face of the indifference they perceive on the part of State officials:

It has been less than a month, and the Attorney who lives comfortably, says he is tired. If I could tell him to his face that we leave our home, sleep where we can, and neglect our work. What is he tired of? Of seeing us demand our rights?

The president [of Mexico] says that we should get over the pain. How will we do that if they haven't returned our children and they make up stories for us? I am deeply humiliated to get that message from the one who supposedly governs. They don't care about our pain. Does he think we can move on with our lives? He's a father; he should understand the suffering for a child.

Out of respect for our families and for us who live in communities, we didn't want the information to be public yet. We asked the Attorney General not to give his version in the media since the investigation was still open, and he did not respect it, he didn't care how we felt. I feel humiliated. Do they want to hurt us more?

According to the authorities' version, the students were deprived of their freedom, deprived of their lives, incinerated and thrown into the San Juan River, in that order. The parents say they feel humiliated and hurt, knowing that this is not a credible version. There is a rupture with the State, and they associate the guarantee of impunity to perpetrators with their social background and poverty:

I feel hurt when I hear the prosecutor's version of events. He is mocking our pain. Showing a version that is not possible without sufficient evidence, as the EAAF says. I no longer trust the authorities in this country, and it hurts me that they speak in public about our children without knowing what happened. They are hurting us even more.

It makes me very angry and impotent that they have invented a version for us, just to calm us down. I feel humiliated. What would they feel if one of their children disappeared? They don't care what happens to us because we are poor. I used to think that being poor was the hardest thing in my life, but now I see that there are more painful things.

Some family members mentioned that approximately one month after the events, they received visits from government agents 
at their homes, with a proposal to "repair the damage" in which they were offered an agreement to have them stop making demands and not to form an organised group, in exchange of money. This was not perceived as a form of reparation but as bribery and an additional humiliation as they understood that a price was being put on their children.

I felt humiliated. Money in exchange for silence? To sell my son? I thought they were coming to support us, to give me another kind of message, but no. The authorities want to shut this down, to stop looking. The authorities want to shut this down, to stop looking. Shut us up in exchange for cash.

Fortunately, my wife and I weren't there," my son told us. My son told us that some welldressed gentlemen had come to make an offer of money. It's a good thing I wasn't in front of them. Do they think that because we are poor, they can continue to offend us?

The independent search by the parents thus became a form of psychological coping and resilience. Weeks after the events, they organised themselves to search for their children in hospital morgues and places where there might be graves. The search confronted the relatives with the possibility of death and generated distressing fantasies about the torture that their relative might have suffered before being disappeared (Antillón, 2016).

When my husband told me they found other graves, he was speechless. He cried and told me that he hoped our son wouldn't be in that condition, that he couldn't get over it.

I don't know why I feel so affected after learning about the bodies in the graves. I have nightmares about it, and I think about what would happen if my son was in a grave and years went by and he was there. I think about how they made them suffer before they killed them, which fills me with rage. They all hurt me, even if I don't know some of them.

As seen in the above testimonies, enforced disappearance, as a traumatic experience, generates a rupture in the life project and a break in basic beliefs about the self, others, and the social world, which can preserve a sense of security to a certain extent and provide a sense of belonging.

\section{Group 3: Mothers of the disappeared}

With the mothers, a critical rapprochement was generated through group sessions, since at first, it was impossible to talk about the emotions related to the events. There was an emotional disconnection as a mechanism of protection. So the focus was on what was tangible: talking about physical pain as a way of expressing emotions (Van der Kolk, 2009).

I come to the workshop to relax, to distract myself a little from so much suffering. Personally; I don't want to talk about anything, no questions.

I feel good here. I like the place; I feel good in my body thanks to our activities. I can relax a bit. I haven't slept for more than a month. It's as if sometimes I don't feel my body.

An essential element in the emotional impact on relatives is the existence of impossible mourning. The enforced disappearance implies a suspension of the person who is absent between life and death and for his or her relatives a constant uncertainty, guilt and fear of confirming the possibility of that death that is at the same time denied. In this context, "to consider him dead is equivalent to killing 
him" (Antillón, 2016). Two fundamental elements for the development of a mourning process are not possible: a) direct knowledge or adequate information about the death of the person and its probable causes; $b$ ) the existence of certain symbolic elements among which we could include funeral rituals, community practices and the social answer towards the mourner (Pelento, Braun, 1985).

As can be seen in the narratives, mothers no longer feel comfortable in their own spaces. The possibility of thinking their children dead generates anguish and guilt:

I moved away from the village because some neighbours tell me that maybe they are no longer alive. Sometimes I think about it, but then I feel guilty, I think there is still hope, and I shouldn't think he is dead. Moreover, I think about whether he's eaten, whether he's hungry, whether he's being treated well. Furthermore, if it's true that my son is already with God, I want to see his body.

I will continue to wait for my son until I am proven otherwise. Don't ask me to kill my hopes.

A fundamental element was identifying the presumed skeletal remains as a space to confront the idea of death. For reasons of neutrality and credibility, the family members agreed that the Argentinian EAAF should accompany the identification process of the remains found in the Cocula River. Due to the deterioration of the fragments, only three were selected to be sent to the genetics laboratory at the University of Innsbruck in Austria. According to the EAAF coordinator, the results confirmed the link to the mother of the student Alexander Mora, with the reservation that the EAAF did not see where the remains handed over by the Attorney General's Office came from.
Although if we believe the EAAF, I doubt that my son is dead. They couldn't see where the bones were, and I think the government put a piece of bone in the garbage dump. I feel sad at the same time, because I think about how he lost a part of him. Will they make him suffer? Besides, what do the authorities think that I will bury a piece of my son? No. I want him alive.

As observed in the narratives, the difficulty in the face of life is maintained over time (Antillón, 2016). Traumatic experiences are often intrinsically impossible to put into words and are sometimes unthinkable because of what this entails (Pérez-Sales, 2007). Trauma, which cannot be symbolised through language, persists in survivors through the repetition of symptoms - especially pain - and the experience that there is a dead part of themselves.

\section{Discussion and conclusions}

The Ayotzinapa case has been a watershed in Mexican society, adding to the history of enforced disappearance in Latin America (GIEI, 2016) through a continuum of life experiences marked both by the events of violence and by the expressions of institutional and structural violence added to the conditions of social marginalisation, poverty and racism (Hernández, 2017).

The results of the group and individual interventions show severe physical, psychological, family and social deterioration due to the events that occurred on September 26th. The events provoked alterations in family dynamics, making it difficult to continue living in their communities. It has been impossible for the family members involved to carry on with their lives as before. The parents continue, years later, with the active search for their children. In addition to the above, the dimension of the impact derived from the lack of 
justice, criminalisation and impunity on State officials contribute to the moral damage on the surviving parents and students. The disappearance of their children resignifies marginalisation and poverty, while these conditions explain the lack of effective search and mistreatment by the authorities (Antillón, 2016).

It is important to emphasise that for the victims, impunity is experienced as a second trauma that relieves the pain and triggers the appearance of symptoms and emotions of anguish and permanent feelings of sadness, rage and impotence. From a psychosocial point of view, it has been documented how legal or political measures that promote impunity generate further harm in the victims (Kordon et al., 1995).

On the other hand, the Inter-American Court repeatedly affirmed that witnessing the torture and execution of others and the immediate and credible desperation and fear of being tortured with extreme cruelty and subsequently executed must be recognised in itself as a form of torture (Pérez-Sales, 2017, Alternative Report to the Committee against Torture, 2012).

Added to the different traumatic events and the magnitude of the damage in the lives of the victims, the action of the Mexican State has generated painful experiences of humiliation, shame and guilt, and they aim to the ultimate purpose of demobilising, provoking the resignation of the relatives. The psychological pain is then engraved in the body and mind of the relatives and ends up becoming part of the victim's identity (Pérez-Sales, 2017). Therefore, trauma is not only an event that occurred at some point in the past; it is also the imprint marked by the subsequent experience and the environment in which this experience had to be faced.

There is a complex relationship between the disappearance and the survivors' attempt to give meaning to life afterwards, marked above all by multiple feelings of guilt, sometimes explicit, sometimes denied or repressed. What underlies is the pressing feeling that their life was made possible by the death of others and the injustice of enjoying life (Gómez, 2013). The traumatic experience of enforced disappearance generates a rupture in the life project and basic beliefs about the self, others and the social world, which have the function of preserving a sense of predictability, control and security (Pérez-Sales, 2006).

In sum, the impact on the direct victims and relatives of Ayotzinapa has unquestionable criteria to be considered torture. It is necessary to see if and how the new reparation mechanisms and the positioning of the Ayotzinapa case on the current government's agenda ${ }^{11}$, at least in words, different from the previous one, will manage to reduce or mitigate the suffering of the victims.

\section{References}

Alonso, C. A. (January-April 2015). To follow the traces of movements at the beginning of the second decade of the twenty-first century. Espiral, XXII (62), 9-42. Available at: http://www.redalyc. org/articulo.oa?id=13832782001

Antillón, X. (2016). Yo sólo quería que amaneciera. Informe de impactos psicosociales del caso de Ayotzinapa. Fundar. Mexico City. Available at: http://ayotzinapa.fundar.org.mx/wp-content/ documentos/DocAyotziFINAL.pdf

United Nations General Assembly, resolution 47/133. (September 1992). Declaration on the Protection of All Persons from Enforced or Involuntary Disappearance. Retrieved from: https://archivos. juridicas.unam.mx/www/bjv/libros/12/5947/7.pdf . Viewed October 30th 2020

Austin, J. (1982). How to do things with words. Barcelona: Paidós.

Beristain, C. (2011). Manual para la perspectiva psicosocial en la investigación en Derechos

11 Commission for Truth and Access to Justice in the Ayotzinapa Case: http://www. comisionayotzinapa.segob.gob.mx/ 
Humanos (Manual on the psychosocial perspective in human rights research). Mexico: CHHDF, Fundar, Serapaz.

Castillo, M. I. (2016). El (im)posible proceso de duelo. Familiares de desaparecidos: violencia política, trauma y memoria (The (im)possible process of mourning. Relatives of disappeared detainees: political violence, trauma and memory). (E. U. Hurtado., Ed.) Santiago de Chile.

Figley, C. B. (1997). Death and trauma: the traumatology of grieving. Washington, DC: Taylor and Francis.

Gándara, S. (2019). La Ley de Desaparecidos falló y familias exigen a AMLO no repetir la omisión y el abandono de Peña. Sinembargo. Retrieved October 29, 2020, from https://www.sinembargo.mx/04$01-2019 / 3516732$

Interdisciplinary Group of Independent Experts (GIEI). (2015). Informe Ayotzinapa.

Investigación y conclusiones inciales de la desaparición y asesinato de los Normalistas de Ayotzinapa. (Ayotzinapa Report. Investigation and initial conclusions on the disappearances and murders of the Ayotzinapa normalistas). Mexico City: GIEI.

Interdisciplinary Group of Independent Experts (GIEI). (2016). Ayotzinapa II Report. Avances y nuevas conclusiones sobre la investigación, búsqueda y atención a las víctimas. Mexico City: GIEI. Available at: https://www.oas.org/es/cidh/ actividades/giei/GIEI-InformeAyotzinapa2.pdf

Gómez, E. (2013). Trauma relacional temprano. Niños de personas afrectadas por traumatización de origen político. (Early relational trauma. Children of people affected by traumatization of political origin). Santiago de Chile: Ediciones Universidad Alberto Hurtado.

Gómez, N. (2009). Efectos psicosociales de la impunida derivada de la no aplicación de justicia en el caso de la masacre de Dos Erres (Psychosocial effects of impunity derived from the non-application of justice in the case of the massacre of the Dos Erres community) (La Libertad, Petén) in December 1982. Retrieved from Available at: http:// www.psicosocial.net/grupo-accioncomunitaria/centro-de-documentaciongac/ violencia-y-cambio-politico/justicia-verdady-reparacion/580-efectospsicosociales-de-laimpunidad-derivados-de-la-no-aplicacion-dejusticia/file

González, R. I. (January-June 2017). La construcción de la "verdad histórica" en las practicas institucionales: el caso ayotzinapa. (The construction of the "historical truth" in institutional practices: the ayotzinapa case). REDHES. Revista de Derechos Humanos y Estudios Sociales, 17, 25.
Gravante, T. (2018). Desaparición forzada y trauma cultural en Mexico: el movimiento Ayotzinapa (Enforced disappearance and cultural trauma in Mexico: the Ayotzinapa movement) . Convergencia .Vol.25. Available at: http://www. scielo.org.mx/scielo.php?script=sci_arttext\&pi $\mathrm{d}=$ S1405-14352018000200013

Hernández, A. (2016). La noche real de Iguala. La historia que el gobierno intentó ocultar. (The real night of Iguala: The story that the government tried to hide). Mexico City. Grijalbo.

Hernández, R. A. (2 (Monaco, 2015)017). "Between Community fustice and International Litigation: The Case of Inés Fernández before the Inter-American Court. ", in R. Sieder, Demanding Fustice and Security: Indigenous Women and Legal Pluralities in Latin America . New York: Routledge University Press.

Illades, E. (2015). La noche más triste. La desaparición de 43 estudiantes en Ayotzinapa. (The saddest night. The disappearance of 43 students from Ayotzinapa). Mexico City: Grijalbo.

Janoff-Bulman, R. (1992). Shattered Assumptions (Towards a New Psychology of Trauma). New York: The Free Press.

Litigio Estratégico en Derechos Humanos, A.C., COFAMIDE, (2012). (2012) Enforced disappearance is also torture! Alternative report to the Committee against Torture with respect to the combined fifth and sixth periodic report of Mexico. Mexico City. Retrieved from: https://tbinternet. ohchr.org/Treaties/CAT/Shared\%20Documents/ MEX/INT_CAT_NGO_MEX_12976_S.pdf

Mónaco, P. (2015). Las horas eternas de Ayotzinapa (Ayotzinapa eternal hours). Mexico City: EDICIONES B.

Ortega, F. A. (2011). Trauma, culture and history: Interdisciplinary reflections for the new millennium. Colombia: Universidad Nacional de Colombia, Facultad de Ciencias Humanas, Centro de Estudios Sociales - CES.

UN Office of the High Commissioner for Human Rights (OHCHR), Fact Sheet No. 6 Rev. 3, Enforced or Involuntary Disappearances, July 2009, No. 6/Rev.3, available at: https://www. refworld.org/docid/5289da9c4.html [accessed December 7th 2021]

Payne, M. (2002). Narrative Therapy: An Introduction for Professionals. Paidos Iberica.

Pelento, M. and. (1985). Disappearance: its impact on the individual and society. APA, 1391-1397. Retrieved January 7th, 2017, from Available at: http://bibliotecadigital.apa.org.ar/greenstone/ collect/ revapa/archives/19854206p1391.dir/ REVAPA19854206p1391Pelento.pdf . 
Pérez-Sales, P. (2017). Tortura psicológica.

Evaluación, definición y medida. Bilbao. Desclee de Brower. (English : Psychological torture.

Definition, evaluation and measurement. Routledge Books)

Ministry of the Interior. (2020). Remarks by Undersecretary Alejandro Encinas, at the Report on Search, Identification and Public Version of the Registry of Persons. Mexico City. Available at: https:/www.gob.mx/segob/prensa/palabras-delsubsecretario-alejandro-encinas-en-el-informesobre-busqueda-identificacion-y-version-publicadel-registro-de-personas?idiom $=\mathrm{es}$

Torres, M. (2017). 15 puntos clave en la nueva ley contra la desaparición forzada. (15 key points of the new law against the disappearance of persons). Retrieved from: https://expansion. $\mathrm{mx} /$ nacional/2017/05/02/15-puntos-clave-de-lanueva-ley-contra-la-desaparicion-de-personas

\section{Acknowledgements}

To the Editor-in-Chief of the Journal, Pau Pérez-Sales, who discussed in different drafts and helped rewrite extensive parts of the paper. 